\title{
Aleksandr Bogdanov and Systems Theory
}

\author{
ARRAN GARE
}

ABSTRACT The significance and potential of systems theory and complexity theory are best appreciated through an understanding of their origins. Arguably, their originator was the Russian philosopher and revolutionary, Aleksandr Bogdanov. Bogdanov anticipated later developments of systems theory and complexity theory in his efforts to lay the foundations for a new, post-capitalist culture and science. This science would overcome the division between the natural and the human sciences and enable workers to organise themselves and their productive activity. It would be central to the culture of a society in which class and gender divisions have been transcended. At the same time it would free people from the deformed thinking of class societies, enabling them to appreciate both the limitations and the significance of their environments and other forms of life. In this paper it is argued that whatever Bogdanov's limitations, such a science is still required if we are to create a society free of class divisions, and that it is in this light that developments in systems theory and complexity theory should be judged.

Aleksandr Bogdanov, the Russian revolutionary, philosopher and scientist, has a good claim to being regarded as the founder of systems theory. ${ }^{1}$ His 'tektology', that is, his new science of organisation, not only anticipated and probably influenced the ideas of Ludwig von Bertalanffy - who must have been familiar with his work, ${ }^{2}$ but anticipated many of the ideas of the complexity theorists. As Simona Poustlinik commented at a recent conference on Bogdanov:

It is remarkable the extent to which Bogdanov anticipated the ideas which were to be developed in systems thinking later in the twentieth century. He anticipated not only a general theory of systems and cybernetics, but also ideas which entered into systems science in the late decades and which are associated with the names of Prigogine, Jantsch and Maturana. ${ }^{3}$

1. Although it has been claimed also that Schelling, who indirectly influenced Bogdanov, was the founder of systems theory. See Joseph L. Esposito, Schelling's Idealism and Philosophy of Nature (London: Associated University Presses, 1977), p. 98ff.

2. Bogdanov's major work on tektology was translated into German in 1926-28, several years before von Bertalanffy published his first works on systems theory.

3. 'Discussion: Philosophical Foundations' in John Biggart, Peter Dudley and Francis King, eds, Alexander Bogdanov and the Origins of Systems Thinking in Russia (Aldershot: Ashgate, 1998), p. 112. 
Bogdanov was a pioneer. He was striving to develop a new conception of the world alien to classical science that could not only replace classical science, but also transcend the division between the human and the natural sciences and between science and philosophy. As such, he had a far broader vision of what this new science should be than later systems theorists. More importantly, Bogdanov had a far more profound view of the significance of this new science. There are then good grounds for claiming that it is through a study of Bogdanov's ideas that we can best understand the potential of systems theory and complexity theory.

As a comprehensive conception of the world, tektology was designed to account for itself and its role in society. Through it, Bogdanov claimed to provide the basis for understanding the achievements and limitations of all previous science, thereby defending tektology as a new advance in science. In terms of it, he developed a theory of physical existence through which the emergence of sentient life could be understood, a theory of life through which the evolution of humans could be understood, and a theory of human history and culture through which the evolution of knowledge and the development of science could be understood. At the same time, tektology was designed to orient people to create a new kind of society. For such reasons it might appear necessary to first expound the basic concepts of tektology and then characterise tektology and its significance from this perspective. However, for our purposes it is more illuminating to see how Bogdanov came to see the need for tektology. So, while presupposing the perspective of tektology, I will begin by describing Bogdanov's political engagement and his epistemology and sociology of culture, and through these characterise what Bogdanov was attempting to do in elaborating his tektology. I will show how it was out of Bogdanov's revolutionary activity and work in economics that he was led to develop his sociology of culture, which called for, led on to, and could then be interpreted in terms of his tektology. Only then will I expound the central ideas of tektology.

\section{Bogdanov the revolutionary Marxist}

Bogdanov was first and foremost a revolutionary. He was born in 1873 and studied medicine at Moscow University and, in 1894, he was banished for his part in a student protest-this beginning his career as a revolutionary. After having worked as a revolutionary propagandist, been arrested and then exiled again, in 1904, he became a founder of the Bolsheviks. He played a major part in the 1905 uprising as a leader of the St Petersburg Soviet and was arrested and gaoled. He led the left wing of the Bolsheviks, eventually losing out in the struggle for dominance to Lenin. Anticipating that a communist uprising would lead either to a technocratic class controlling a capitalist economy or a form of war communism that would reduce the population to serfs and eventually stagnate, Bogdanov opposed the October revolution of 1917. His political goal was to create a society in which the division between the organised and the organisers would be overcome, and to this end he promoted and worked towards the creation of a new 'proletarian' culture. This would be the future socialist culture, a culture through which workers would be able to control their own 
destinies. After the revolution, Bogdanov founded the Moscow branch of the Proletarian Culture Movement (Prolekult), which was formally instituted as an all-Russian organisation in 1918. In that year, he became the first director of the Socialist Academy of Social Science, a position he held until 1923. Lenin continued to perceive Bogdanov as a threat, doing everything he could to destroy the Proletkult movement; and indeed the Workers' Opposition, which sought to democratise factories, and socialists, who perceived the revolution as having been betrayed by Lenin's New Economic Policy, were partly inspired by Bogdanov's ideas. After Lenin's death in 1924, Zinoviev, Kamanev and Bukharin asked Bogdanov to rejoin the Bolsheviks, hoping to bring him into collaboration against Stalin - an invitation he declined. In 1926, he founded the first Russian Institute for Blood Transfusion, and died in 1928 after exchanging his blood with a seriously ill patient (who survived).

While Bogdanov had embraced Marxism, originally he had been a Narodnik, and unlike other Marxists, never repudiated his early anarchist ideas. He was vehemently opposed to the dogmatism of Marxists, which he equated with outmoded authoritarian and religious frames of mind. He was critical of Marx's ideas, rejecting the way he had divided social reality into base and superstructure and rejecting the determining role Marx had ascribed to the forces of production. For Bogdanov, what was crucial in Marx's thought was his emphasis on the primacy of social praxis. Economic life is an integral part of social being, and social being is identical to social consciousness. Knowledge, as the core of social consciousness, is the moving force of history and the main line of social progress. Taking knowledge as a sociological rather than an epistemological phenomenon, Bogdanov argued that the study of the inner dynamics of social relations is equivalent to the study the development of knowledge. An analysis of co-operation within individual groups provides the basis for a study of general forms of knowledge, characteristic of the entire society and the basis for identifying special ideological tendencies. ${ }^{4}$ In his later writings the categories social being and social consciousness were merged in the category 'culture'. The central theme of Bogdanov's sociology was then the regularities in social changes as recorded in cognitive culture.

Reformulating Marx in a way that anticipated the work of Habermas, Bogdanov argued that social being has two levels, the technical and the organisational. The organisation of activity at the technical level generates technical knowledge or technology. For Bogdanov, technology denotes not material equipment but the organisation and utilisation of knowledge related to

4. A.A. Bogdanov, Poznanie s istoricheskio tochki zreniia [Knowledge from an Historical Point of View] (St. Petersburg, 1902), p. 193f.; translated and quoted by Alexander Vucinich, Social Thought in Tsarist Russia (Chicago: University of Chicago Press, 1976), p. 212.

5. See A.A. Bogdanov, 'Razvitie zhizni v prirode i v obschchestve', in Iz psikhologii obshchestva [From the Psychology of Society] (St. Petersburg, 1904). This development is described by John Biggart in 'Marxism and Social Anthropology', Studies in Soviet Thought, Vol. 24 (1982), pp. 1-9, esp. p. 4. Biggart argues that this could have been an indirect source of inspiration for the American school of 'cultural materialists'(Leslie White, Julian Steward, Betty Meggars and Marvin Harris). 
external nature. As the technical level became more complex, humans needed more complex organisational forms. This is the realm of ideology, or what has been called in idealist philosophy, the realm of spirit-concepts, thought, norms-all of those things which are called ideas in the broadest sense of the word.

\section{Bogdanov's sociology of knowledge}

While Bogdanov's first work was in economics, he soon turned his attention to characterising knowledge and culture. Following the empirio-critics (Mach and Avenarius) Bogdanov fully embraced the idea that what is real is experience, and that the goal of knowledge is to orient people therein. Arguing from 'the labour point of view' or 'the point of view of collective labour activity', Bogdanov argued that experience is the sum total of all human effort and resistance to that effort. Elements of experience are separated out to accord with the needs of production. They are the product of a certain amount and type of effort directed against a certain amount and type of resistance. Such activity is first physical and then mental; one first makes a brick as a physical element and then forms the idea of bricks. For Bogdanov, the physical and the psychical differ in being different levels of organisation of experience. While physical experience is the product of social organisation, the psychical is individually organised experience within the limits of personal life. The objectivity of the physical does not have a basis in epistemology but has a sociological basis as the product and reflection of social-labour organisation. Both physical and psychical knowledge are the products of long historical developments, the gradual, but inexorable expansion of social experience, which has produced the growing complexity, depth and precision of humanity's organisation of experience.

Bogdanov argued that all advances in knowledge are based on 'substitution'. Knowledge is organised by cognitive models through substitution. Substitution begins with language. For instance the word 'anger' is a substitute for certain gestures and facial expressions. Through substitution people can understand one another and can explain the sense of their actions. From this elemental level, substitution has been carried over to all other levels of experience to understand, predict and explain, and to facilitate the control of nature. The process of substitution involves taking an object and effectively changing it into something else, while at the same time admitting the essential difference. For instance to say that the sun is a star, a conglomeration of gases in space which behaves according to the laws of motion, is to substitute something for the sun as it is visually apprehended by people. One complex of elements of experience is replaced by another. Substitution is employed at all levels of thought, including philosophical and scientific explanation. In general, advances in understanding are made by substituting for a simpler, less plastic complex with which relatively little may be done in practice or consciousness, a complex which is more subtle, more plastic and therefore more useful-hence the tendency towards mathematical models in science. Substitution is the basic method for bringing all experience into a unified whole. What is required is not the abolition of substitution but a readiness to substitute indefinitely, and a recognition of the 
practical and conscious activity involved in such organisation of experience. Bogdanov called for 'infinite substitution'.

One of the problems raised by the theory of substitution is where do the substitutes come from. Bogdanov elaborated a new form of the dialectic to account for this - a dialectic of social labour. He argued that workers who initially develop their separate perspectives through labour, come into conflict, which is intensified by the urge to complete a task. The conflict is resolved when one workers' perspective prevails over the other, or some third perspective is generated which is agreed upon. This scheme, "created in one realm of social experience, may then be applied beyond its limits to other realms of phenomena, social and extra-social'. ${ }^{6}$ This, Bogdanov characterised as the 'law of sociomorphism'. Cognitive models that are used as substitutes may originate in simple social-labour practice, in the methods of social-labour technique, or in economic relations. Cognitive forms taken from the real world in this way then reinforce the way this world is organised. Particular substitutes are taken as absolute, are fetishised and treated as idols, just as the institution of property is fetishised and idolised in capitalist society. For instance, Bogdanov argued that:

... the savage living in a commune which is organized on the basis of authoritarian leadership and passive submission, thinks, that is, organizes in his consciousness, of the entire universe in the same way: he thinks of the ruling god and the people and things subordinated to him; and he organizes them in his thought into the ruling, leading soul and the passive body. ${ }^{7}$

Conceiving of the universe in the same way, fetishising the authoritarian relationship that is being used as a substitute, legitimates such authoritarian leadership and makes it difficult to even conceive the possibility of organising society in a different way. Extending this theory of substitution, Bogdanov argued that atomism originated in ancient thought when individualism developed in society setting men apart. People were accustomed to think about themselves and others as isolated entities, and they transferred this habit onto notions about nature: in Greek, 'atom' means an 'individual', and in Latin it means 'indivisibility'. ${ }^{8}$ Atomism is then fetishised and used to legitimate such individualism. In Philosophy of Living Experience (first published in 1913), Bogdanov used this way of analysing the source of cognitive models to explain the history of materialist philosophy from the pre-Socratics to the materialists of the nineteenth century, showing how the dualism between an active mind and passive matter is a reflection of a society which divides intellectual from manual labour and the organisers from the organised. He also explained the ideas of the empirio-critics, whom he noted were socialists, as the product of a new class within capitalist

6. A.A.Bogdanov, Filosofiia zhivogo opyta [Philosophy of Living Experience], 3rd edn (Moscow: Kniga, 1923) p. 218; cited by K.M. Jensen, Beyond Marx and Mach: Aleksandr Bogdanov's Philosophy of Living Experience (Dordrecht: Reidel, 1978), p. 93.

7. A. Bogdanov, Essays in Tektology: The General Science of Organization [1921], 2nd edn (Seaside, CA.: Intersystems Publications, 1984), p. 29.

8. Bogdanov, Essays in Tektology, p. 29. 
society between the bourgeoisie and the proletariat which had partially overcome the division between intellectual and manual labour, and by virtue of this, had come to see the substitutions of past science as fetishes, just as they had come to recognise that property is a fetish. ${ }^{9}$

This theory of knowledge has dramatic implications. It implies that the limitations in the science of Bogdanov's own time were at least in part a manifestation of the limitations of the form of society scientists were living in, and conversely, that the existing social order was being maintained by the fetishised substitutions of such defective forms of knowledge. Bogdanov not only interpreted and evaluated the knowledge of his day in relation to past knowledge. Constructing his history of science involved projecting the direction science should take in the future; and he strove to lay the foundations for this new science. Since he saw science as indissociable from social conditions, he was able to project what social conditions would be needed to develop this new science-social conditions that he believed would also require this new science. What Bogdanov called for, and devoted most of the rest of his life promoting and developing, was the creation of a new way of organising experience, a proletarian culture.

\section{The need for a cultural revolution}

As Bogdanov understood it, the failure of the revolution of 1905 had shown that the workers were not yet prepared to take political power and that even if they gained political power, they were not culturally prepared to create a genuinely socialist society. Unlike Lenin whose major concern was with the seizure of power, Bogdanov was more concerned with the longer-term project of creating a socialist society. ${ }^{10}$ It followed from Bogdanov's social theories that it is not the property relations of capitalism, which are the most important means of domination in society, but the way production is organised. And since social labour is based on the organisation of experience, what is required to change the way production is organised is the creation and development of new ways of organising experience, a struggle against the fetishisms and idols which have prevented people appreciating that the organisation of production and social relations could be different. Socialism cannot be achieved by a revolution of property, a change in rulers of society-it is not just a matter of class interests and material force of the masses. It requires a creative revolution of world culture, a change from spontaneous education and struggle of social forms to conscious creation-a matter of a new class logic, new methods of unifying forces, new methods of thinking. ${ }^{11}$

9. Jensen, Beyond Marx and Mach, pp. 50-66, 81-86.

10. On this see James C. McClelland, 'Utopianism versus Revolutionary Heroism in Bolshevik Policy: The Proletarian Culture Debate', Slavic Review, Vol. 39, No. 3 (September 1980).

11. Bogdanov, 'Ideal i put', in Voprosy sotsializma [Problems of Socialism] (Moscow: t-vo. knigoizd. pisatelei v Moskve, 1918), p. 100f.; cited by Zenovia A. Sochor, Revolution and Culture: The Bogdanov-Lenin Controversy (Ithaca: Cornell University Press, 1988), p. 39. 
Apart from property relations and the organisation of production, all social relationships based on domination and subordination, whether these be based on sex, race, class, nationality or possession of technical knowledge, are sources of conflict which must be criticised and overcome by the proletariat. As Bogdanov put it: the struggle for socialism is not by any means to be equated with an exclusive war against capitalism. It involves the creation of new elements of socialism in the proletariat itself, in its internal relations and in its conditions of everyday life: the development of a socialist proletarian culture. ${ }^{12}$ Bogdanov also paid attention to male-female relationships as problematic, as needing to be transformed by the proletariat. ${ }^{13}$ Consequently, a genuine revolution is not something that could be achieved by one gigantic act of will in which power is seized, but is a transformative process involving many levels. Only when the proletariat can oppose the old cultural world with its own political force, its own economic plan and its new world of culture, with its new, higher methods, will genuine socialism be possible. ${ }^{14}$

Art, literature, philosophy and science were all accorded importance by Bogdanov as ideological labour, their object being a transformation of the way people organise their experience to achieve a common understanding of the world. In opposition to orthodox Marxists, Bogdanov argued: 'Art ... is a most powerful weapon for the organization of collective forces and, in a class society, of class forces'. ${ }^{15}$ The ultimate goal of ideological labour is overcoming the divisions between people and the creation of a collective of creative individuals with a common will which can be appreciated as such by each individual member of this collective. This is associated with overcoming the alienation of people from each other and the affirmation by them of their collective power. In the new society, with the overcoming of class and other divisions, the psychology of disconnectedness will be replaced by the recognition of the self as an integral part of the great whole. ${ }^{16}$ This is Bogdanov's answer to Sorel's reinterpretation of Marx to celebrate not the scientific analysis of society, but the provision of a myth which gave the working class something to live for, and more importantly, to the challenge of Nietzsche, who diagnosed the nihilism of the age as a consequence of the triumph of slave morality, as the will-to-power turned against itself, a triumph which would be only more complete if socialists

12. Bogdanov, 'Sotsializm v sastoiashchem', Vpered, Vol. 2 (February 1911), p. 68.

13. On this, see Loren R. Graham, 'Bogdanov's Inner Message', in Loren R. Graham and Richard Stites, eds, Alexander Bogdanov, Red Star: The First Bolshevik Utopia (Bloomington: Indiana University Press, 1984), p. 244. Alexandra Kollantai, the leading Bolshevik feminist and a leader of the Worker's Opposition, was a disciple of Bogdanov.

14. Bogdanov, 'Programma kul'tury,' in Voprosy sotsializma, p. 73 (cited by Sochor, Revolution and Culture, p. 39).

15. Cited by James C. McClelland, 'Utopianism versus Revolutionary Heroism in Bolshevik Policy: The Proletarian Culture Debate', Slavic Review, Vol. 39, No. 3 (September 1980), p. 403 without reference.

16. Bogdanov, 'Tseli i normy zhinzi', in Novyi mir, 3rd edn (Moscow, 1920); cited by Sochor, Revolution and Culture, p. 197. 
were to prevail. ${ }^{17}$ Bogdanov's was not a socialism of negation, of ressentiment, but a socialism that affirmed the human will.

According to Bogdanov, science would be the most important component of the new culture because it bridges the gap between ideological and technological knowledge. Recent developments in science, themselves manifestations of the change in work and work relations, were seen to be already portents of the new socialist society. In societies with an authoritarian structure, such as ancient or feudal societies, cause is understood to predominate over effect as something strong and active. Regularities in the material world are seen as produced by spirit, by something transcending the world. With the development of capitalist society effect is understood abstractly as following cause out of some sort of natural or logical necessity, independent of human will and experience, reflecting the powerlessness of people before the impersonal imperatives of the market. With the development of more complex technology bringing a closer relationship between labour and the control of production, a new concept of causation has emerged within science. Machine production changes the world by turning the physical, chemical and electrical forces into one another as natural forces are turned into the mechanical forces of production. In essence, machine production is 'the systematic transformation of efforts, or, in scientific and exact terms, the transformation of "energy", 18 Bogdanov rejected the fetishistic concept of energy as a thing in itself, and also the notion of it as a useful fiction; the first because it represents energy apart from labour activity, the second because it conceives energy only in relation to thought and not in relation to action. The concept of energy arises from the use of labour causality as a substitute, and it should be recognised as such. Energy represents the practical relationship of society to nature, of human activity to that which resists it. The transformation of energy refers to the creation and change wrought by active, human effort on resisting nature; "to see "energy" in the processes of nature means to look at those processes from the perspective of their possible labour exploitation by man'. ${ }^{19}$ Since neither effort nor energy is either created or destroyed in production, but simply takes on different appearances and uses, cause and effect modelled on the transformation of energy must appear as equal, as simply 'different phases in a continuous series of changing and changeable phenomena'. 20

This change foreshadows a situation where workers will cease to be mere labourers and will control production. Then, labouring will be recognised as the organisation of the series of changing and changeable phenomena and labourers will appreciate work as such. As manual work becomes increasingly organisational and intellectual, labourers will first unite with the technical intelligentsia,

17. See Sochor, Revolution and Culture.

18. Bogdanov, Philosophy of Living Experience, p. 268f. (cited by Jensen, Beyond Marx and Mach, p. 120).

19. Bogdanov, Philosophy of Living Experience, p. 271 (cited by Jensen, Beyond Marx and Mach, p. 122).

20. Bogdanov, Philosophy of Living Experience, p. 270 (cited by Jensen, Beyond Marx and Mach, p. 121). 
then become worker-engineers, and finally will become worker-scientists. This will be associated with the overcoming of the specialisation of society based on capitalist exchange relations. What is required to bring this about, for labourers to become worker-scientists able to appreciate all aspects of production, the dynamics of societies and the dynamics of nature, and simultaneously, what will emerge with the overcoming of specialisation based on capitalist exchange relations, is a new science which focuses on the general features of all organisation and which thereby systematises the entire cognitive experience of the past, including experience of social relations. Bogdanov believed that the greatest contribution he could make to creating a proletarian culture was founding such a science of organisation. He devoted most of the rest of his life to this, producing what he regarded as his most important work, Tektology: The Universal Organizational Science (from the Greek word 'tekton', meaning 'builder' - a term Bogdanov took from Haeckel's morphology). ${ }^{21}$

\section{Tektology}

Bogdanov described Tektology in his autobiography as 'a general study of the forms and laws of the organization of all elements of nature, practice and thought'. ${ }^{22}$ According to him, 'we, people, are organizers of nature, of ourselves, and of our experience', and he examined 'our practice, cognition and creativity from the organizational point of view' ${ }^{23}$ Moreover Bogdanov believed that our organisational experience could be used as a substitute for understanding the rest of nature and argued that this provides the basis for a monistic world-view, allowing us to see ourselves as self-organising parts of a self-organising nature. It is not only we who organise. Nature itself is the first great organiser and humans are only one of its organised products. 'Inorganic' nature is highly organised. 'Matter', Bogdanov argued, 'with all of its inertia, is being perceived as the most concentrated complex of energy, that is, precisely activities; its atom is a system of closed motions, the speed of which exceeds all others in nature ${ }^{, 24}$ and the simplest of living cells 'surpasses in complexity and perfection of its organization all that man can organize'. ${ }^{25}$ Bogdanov concluded:

Thus, the experience and ideas of contemporary science lead us to the only integral, the only monistic understanding of the universe. It

21. A.A. Bogdanov, Tektologia: Vseobshchaya Organizatsionnay Nauka [Tektology: The Universal Organizational Science], Vol. I (St. Petersburg, 1912); Vol. II (Moscow, 1917); Vol. III (Moscow, 1922). The revised, third edition of 1925 was recently republished in two volumes (Moscow: Ekonomika, 1989). The first volume of this has been translated, edited by Peter Dudley, and published as Bogdanov's Tektology, Book 1 (Hull: Centre for Systems Studies Press, 1996), p. 72ff. Essays in Tektology is essentially a condensation of the three volume work.

22. Georges Haupt and Jean-Jacque Marie, eds, Makers of the Russian Revolution: Biographies of Bolshevik Leaders, trans. C.I.P. Ferdinand and D.M. Bellos (Ithaca and New York: Cornell University Press, 1974), p. 288.

23. Bogdanov's Tektology, Book I, p. 4.

24. Bogdanov, Essays in Tektology, p. 42.

25. Bogdanov, Essays in Tektology, p. 5. 
appears before us as an infinitely unfolding fabric of all types of forms and levels of organization, from the unknown elements of ether to human collectives and star systems. All these forms, in their interlacement and mutual struggle, in their constant changes, create the universal organizational process, infinitely split in its parts, but continuous and unbroken in its whole. ${ }^{26}$

The basic focus of Tektology is on the necessity to study any phenomenon from the point of view of its organisational activity, since all activities of humans and of the rest of nature are primarily organisation and disorganisation of elements on hand. The work attempts to systematise the fragmented knowledge of organisational methods so they can be studied and developed to reveal structural relations and laws common to the most heterogeneous phenomena, to reveal the most general characteristics of organisational activity. Aspects of organisational form considered are wholeness, self-regulation, transformation and development; equilibrium and disequilibrium; and stability, instability and crises.

To establish which modes of organisation can be observed and to explain them it is necessary to examine elements and their combinations into complexes (or complex systems), where elements are understood as activities-resistances of all possible types. ${ }^{27}$ It should be noted, however, that elements cannot be identified absolutely but only relative to particular complexes; what is elemental from the perspective of one complex might itself be complex, and what from one point of view are activities will be from other points of view resistances. 'Complexes' are combinations of elements with a particular structure able to resist the activities of other complexes. If a complex has greater effect against resistances than its elements, it is organised, if it achieves the same effect it is neutral, and if less, disorganised. ${ }^{28}$ 'A disorganised whole is practically less than the sum of its parts', wrote Bogdanov. ${ }^{29}$

The formation, nature and fate of complexes are governed by formulating and regulating tektological mechanisms. ${ }^{30}$ The formulating tektological mechanisms, those which create or destroy a complex, are defined by the concepts 'conjunction' (that is, the joining of complexes), 'ingression' (the entering of common links between the elements being joined), 'linkage' (the entry of elements of one complex into another, for example, the common object of co-operatively organised efforts, or the merged parts of bacteria which belong to both bodies), 'disingression' (the disintegration of conjugated systems to form separate complexes) and 'boundary' (that which divides such complexes). There are various types of integration of complexes, but Bogdanov focussed on two in particular, 'egression' and 'degression'. ${ }^{31}$ Egression involves a differentiation between degrees of interdependence and influence among systemic elements (for instance between managers and staff in a business organisation, or the brain and other

26. Bogdanov, Essays in Tektology, p. 6.

27. Bogdanov's Tektology, Book 1, p. $72 \mathrm{ff}$.

28. Bogdanov, Essays in Tektology, ch. 2.

29. Bogdanov, Essays in Tektology, p. 43

30. Bogdanov, Essays in Tektology, ch. 3; Bogdanov's Tektology, Book 1, ch. 3.

31. Bogdanov, Essays in Tektology, ch. 6. 
organs in a body). Degression involves a differentiation between a stable, but less plastic part and a plastic, but less stable part (for instance between a skeleton and flesh), or between the core ideas of an ideology and variations adapted to diverse circumstances (equivalent to the hard core of a scientific research programme and its auxiliary hypotheses).

Stability and instability is central to tektology. Conceiving complexes as dynamic and continually interacting with and assimilating or disassimilating elements from their environments, stability is always only a matter of degree and needs to be explained. Stability is dependent 'not only on the quantity of activities-resistances concentrated in it, but also on the mode of their coupling and the character of their organizational connections'. ${ }^{32}$ Structural stability, for example, the resistance to bending or breaking, represents a magnitude that can be expressed quantitatively. When instability finally reaches a point of radical change, we have a crisis. Characterising form as 'a totality of connections among elements', Bogdanov argued that 'a change in form can only consist either in a destruction of any former connections or in the appearance of new connections, or in both'. So, 'the essence of crises lies in the formation or violation of complete disingressions ${ }^{33}$ Phase transitions, electrical discharges and a variety of chemical, biological and social changes were all characterised as crises in this sense and Bogdanov argued that crises are ubiquitous in nature, society and the psyche. He distinguished between two kinds of crisis, 'crisis C' (conjunctive crisis-associated with the conjoining of complexes) and 'crisis D' (disjunctive crisis-associated with the disintegration of complexes). ${ }^{34}$

Development, increasing instability and crisis are illustrated in a simple way by the growth and breaking up of a dewdrop. Here stability, instability and crisis are a simple function of the quantity of water. Stability and instability and subsequent transformations of a more complex kind are illustrated by the development of ideologies. Ideologies were characterised by Bogdanov as degressive complexes:

[S]ymbols in general, and their main group,-words and concepts-in particular, perform a skeletal role for the socio-psychic content. ... Consequently, the nature of ideologies is generally degressive, skeletal, with all the related features .... So, beginning with the simplest example, the word not only secures the living content of experience, but also hampers the future development of experience by its conservatism. In science and philosophy, the customary but obsolete terminology is often a serious obstacle to progress, preventing the mastery of new material, and distorting the meaning of new facts which it cannot express fully and precisely. But this contradiction appears even more vividly in the development of more complicated complexes .... ${ }^{35}$

32. Bogdanov, Essays in Tektology, p. 88.

33. Bogdanov, Essays in Tektology, p. 232.

34. Bogdanov, Essays in Tektology, p. $241 \mathrm{ff}$.

35. Bogdanov, Essays in Tektology, p. 195. 
Describing the Catholicism of Europe at the end of the Middle Ages in such terms, Bogdanov described how: 'The new living content, bursting out of the framework of the old dogma, created new degressive forms for itself: along with the religious system of ideas and norms there were worked out scientific and philosophical ones' ${ }^{36}$

Bogdanov argued that there is a tendency of initially similar complexes to diverge as initial changes are reinforced by the variety of the environment (with some counter-tendency generated by similar environments towards convergence). Divergent complexes then conjoin to form new complexes. But the degrees of separateness and connectedness of complexes generated in this way are quite varied. The joint effect of the tendency to divergence and to interconnectedness is that 'differences grow, leading to increasingly more stable structural correlations, ${ }^{37}$ That is, we have what has come to be called 'co-evolution'. ${ }^{38}$ This was shown by Bogdanov to be involved in the differentiation of cells to form multi-celled organisms, the development of 'psychics' and the development of 'languages, science, law, ethics and, generally, any complex cultural form' ${ }^{39}$ It is also associated with the development of the whole sphere of life, the biosphere, as a single system of diverging forms, and the biosphere, hydrosphere and atmosphere as parts of an even wider system. ${ }^{40} \mathrm{In}$ this way, the various forms of selection were shown to constitute the entire dynamics of evolution of non-living and living phenomena on earth, including the dynamics of culture and the psyche, accounting for emergence, conservation, stability, development, divergence, instability, radical transformation and destruction of complexes, and the integration of complexes at multiple levels to the biosphere and the bio-hydro-atmosphere of which the biosphere is part.

According to Bogdanov, tektology would not only enable workers to become self-organising; it would facilitate a deeper understanding of all past science and all past social forms. It would also provide a perspective from which not only human history would become intelligible, but also natural history. Once the divisions between intellectual and manual labour, the organisers and the organised have been overcome and people have come to experience themselves as self-organising activity, they will be able to free themselves from the old fetishes and corresponding dualisms and appreciate that all of nature consists of self-organising activities. They will also be able to appreciate the intrinsic significance and diversity of these. ${ }^{41}$ So while the past of human history is made sense of on the assumption that all knowledge is oriented towards controlling nature, society and individual experience for human purposes, and all past

36. Bogdanov, Essays in Tektology, p. 195.

37. Bogdanov, Essays in Tektology, p. 128.

38. Alexander Orgurtsov, 'Bogdanov and the idea of co-evolution', in Biggart et al., Alexander Bogdanov and the Origins of Systems Thinking in Russia, pp. 254-264.

39. Bogdanov, Essays in Tektology, p. 129.

40. Bogdanov, Essays in Tektology, p. 130; Bogdanov, Tektologia: Vseobshchaya Organizatsionnay Nauka, Vol. 2, 1989, p. 17.

41. On Bogdanov's defence of the intrinsic significance of all life forms, see Bogdanov, Red Star, p. $116 \mathrm{ff}$. 
knowledge is interpreted in terms of such labour activity (i.e. instrumentally), humans will be able to appreciate that they are merely one form of organising activity among others (i.e. realistically). Science itself will be comprehensible as a development within and of nature. As Marx argued in a work unknown to Bogdanov, The 1844 Manuscripts:

Communism is the riddle of history solved, and it knows itself to be this solution. ... [N]atural science will lose its abstractly material-or rather, its idealistic - tendency, and will become the basis of human science. ... Natural science will ... incorporate into itself the science of man, just as the science of man will incorporate into itself natural science: there will be one science. ${ }^{42}$

\section{Tektology, systems theory and complexity theory}

Tektology can be evaluated in a number of ways. Firstly, it can be evaluated as an advance in the sciences. As noted, tektology anticipated most of the developments of systems theory and much of complexity theory, although tektology was presented in non-mathematical form where most systems theorists and complexity theorists have been pre-occupied with the development of mathematical models of their objects. However, this highlights a difference between Bogdanov and many of the proponents of systems theory and complexity theory. Tektology should be seen in relation to a broader tradition of thought, which claims that processes are the primary reality rather than things or substances and their attributes. As Milan Zeleny noted of Bogdanov's notion of complex, it 'is not simply a collection, aggregate (or vector) of components and their relationships'. It is 'a process, or continuous flux of independent component-producing processes, concatenated in self-triggering circles of buildup and degradation. ... [I]t does not exist or interact with its environment: it is structurally coupled with its environment and thus evolves its own environment while co-evolving with it. ${ }^{43}$ If this is the case, then a non-formal language is more appropriate for characterising the basic characteristics of what there is, and mathematics should be seen as having a derivative status. This is the view that has been argued for by Bergson and Whitehead among philosophers, and C.H. Waddington, Ilya Prigogine and David Bohm among scientists. Seen in this way, tektology should be evaluated as an overarching, co-ordinating framework of concepts able to guide and make sense of specific research over the whole range of the sciences, physical, biological, cultural, social and psychological. In this regard, tektology is highly successful. It can give a place to advances in systems theory and complexity theory while avoiding the tendency towards new forms of reductionism characteristic of both systems theory and complexity theory,

42. Karl Marx, Economic and Philosophic Manuscripts of 1844, trans. Martin Milligan (New York: International Publishers, 1964), pp. 135 and 143.

43. M. Zeleny, 'Tectologiya', International Journal of General Systems, Vol. 14, No. 4 (1988); cited by Vadim N. Sadovsky and Vladimir V. Kelle, 'Foreword', Bogdanvo's Tektology, Book 1, p. xviii without page numbers. 
particularly in the human sciences. With some minor modifications and additions, tektology is also consistent with developments in physics, chemistry and biology, notably the quantum theories of de Broglie and Bohm, Prigogine's work on dissipative structures, and the work of Goodwin and other 'process structuralists' in biology. More significant is tektology's relevance to the human sciences. Bogdanov's work is still relevant to understanding the dynamics of cultures, to analysing the present state of capitalism and to revealing what opportunies there are to creating new forms of society. Also, there are dimensions of tektology that are promising and still to be developed.

However, if Bogdanov is right, what is more important is to have begun the project of creating such a co-ordinating framework of concepts, to have carried this through consistently and to have revealed the social conditions and social implications of ideas within the sciences. Since Bogdanov, other historians of science have examined the close relationship between ideas upheld as scientific and socio-economic and gender relations. Joseph Needham and Margaret Jacobs have shown the ideological function of mechanistic thinking in the emergence of capitalism in the seventeenth century. Robert Young, Adrian Desmond and James Moore have shown the ideological role of Darwin's evolutionary theory in nineteenth century capitalism. Richard Levins and Richard Lewontin have pointed out the continuing role of reductionist Darwinian ideas in upholding late capitalism and in legitimating the dissolution of the welfare state. Feminists and environmentalists such as Evelyn Fox Keller and Carolyn Merchant have exposed the biases produced by oppressive gender relations in favour of scientific theories that facilitate the domination and control of nature and people. Other social theorists, notably Lukacs, Gramsci (who was probably influenced at least indirectly by Bogdanov) and members of the Frankfurt Institute have argued for the central importance of consciousness and culture in preventing or facilitating the creation of a new society. However, with the exception of Needham, Lewontin and Levins, these historians, scientists and social theorists have not taken the next logical step of considering how science could be reformed, how a science free of the forms of thinking generated by a hierarchically organised capitalist society could be developed and what role it might play in the creation of, and as a component of, the new socio-economic and political forms. Bogdanov not only took this logical step, but also went a considerable step towards developing such a science. Of course his whole argument for the importance of creating a new science could be rejected. So far no one has argued against it; but by their response it is clear that most radicals do not take the argument seriously. The exceptions to this, notably Needham and Castoriadis, have made little effort to defend the argument or to show how a new science would facilitate the transformation of society. This situation calls for further examination of the argument.

To understand Bogdanov's views it is necessary to appreciate that Bogdanov was first and foremost a revolutionary. Unlike Lenin and many other purported socialists, Bogdanov was a genuine revolutionary. That is, he was working towards the creation of a society in which people would cease being the instruments of others and would gain control over their own destinies. If people are to control their own destinies then what they need first and foremost are the 
means to orient themselves, both individually and collectively, to understand their situations in both the physical and social world in order to formulate projects, make decisions and act. They need the means to understand the dynamics of nature to produce goods and sustain themselves, to understand themselves, to comprehend their own potentialities, appreciate what they can realistically aspire to and to understand the nature and dynamics of society. Only in this way will they be able to appreciate what social forms are inimical to their interests, what powers these forms have and what are the possibilities for creating new social forms. These new forms require frameworks of ideas that can serve as the basis for deliberations and arguments about what projects to pursue. More basically, if people collectively are to believe that they can create social forms based on the appreciation of the significance and ability of people to be creative, it is necessary to justify the conception of humans as creative agents. This is only possible by showing that nature is such that it is capable of generating beings who are self-creative, and this requires a conception of nature as consisting of self-creative beings, which in turn leads to an appreciation of their intrinsic significance. Furthermore, this leads to an appreciation that all creativity is dependent on the destruction, survival and development of other forms, and that economic development improperly undertaken could lead to the destruction of natural forms which are the conditions for the continued flourishing of humanity. This, essentially, is the logic underlying the development of Bogdanov's ideas.

This logic is so compelling that the failure to accept it by purported radicals looks suspicious. It could be due to ignorance of Bogdanov's philosophy and lack of acquaintance with his argument. It could also be due to ignorance of science and a blindness to the real world, a blindness engendered by academic life of what is involved in economic production and what is involved in the political and ideological domination of some people by others. It might also be argued against Bogdanov that like other Marxists, he over-emphasised the importance of economic activity to social life and even while granting a central place to 'ideological' labour, failed to appreciate the importance of political organisation and activity. However, it is more likely that deeper issues are involved; that purported radicals have no real faith in the ability of people to control their own lives and are using the plight of the downtrodden not to justify a radical transformation of society but to justify their own struggle for power. Indeed, this was fully appreciated by Bogdanov who pointed out to the detractors of the Proletkult movement, 'if [proletarian culture] were beyond one's strength, the working class would have nothing to count on, except the transition from one enslavement to another, [that is,] from under the yoke of capitalists to the yoke of engineers and the educated. ${ }^{44}$ Even when we accept arguments of Bookchin, Castoriadis and Fotopoulos for the importance of political life, this does not affect Bogdanov's argument. The democratic organisation of society at all levels requires a new, non-reductionist science that allows for the appreciation of the creativity of nature, society and individuals.

44. A.A. Bogdanov, 'Ideal i put', in A.A. Bogdanov, Voprosy sotsializma (Moscow, 1918); cited by Socher, Revolution and Culture, p. 186. 


\section{Objections to tektology}

While, as we have seen, proponents of Bogdanov's tektology have justified it by calling attention to how it anticipated systems theory and complexity theory, this could also be used against it. Systems theory in particular has come under attack by radicals as an instrument of management and control by governments and business organisations associated with the more active role of the State and the expansion of capitalism after the Second World War. The new science of management that emerged was designed to enable managerial elites to control society in their interests. The 'socio-technical systems theory' that developed from this united information theory, cybernetics, operations research, games theory and cost-benefit analysis with systems theory into a generalised instrument for control. ${ }^{45}$ In doing so, it refined and reintegrated the mechanistic conception of humanity rather than replacing it, and enabled Social Darwinism to be reformulated and revived. As Mike Hales pointed out:

Although developed in reaction to the mechanistic nature of Taylorism, the socio-technical approach contains its own form of mechanism, rather broader in conception and more subtle, but still mechanistic. The operator of an effectively designed automated system fits into the machinery of production in as calculated a way as does the assembly-line worker. ... Management science which leans on systems theory tends to have a strong stream of cybernetics in it, and both system theorists and cyberneticians view organisms and organizations as organic machines in which the parts are significant only with respect to the functions they perform in the adaptation of the whole to the environment. ${ }^{46}$

Paralleling this development, it appears that tektology was reformulated and developed as an instrument of control in the Soviet Union, especially with the rise of Stalin and it is this history that is seen to be behind efforts to rehabilitate Bogdanov in Russia. ${ }^{47}$ It is systems theory in this form, which has provoked a justifiable reaction from radicals, ranging from Habermas' efforts to contain it to Lyotard's total rejection of it.

The case of complexity theory, while to some extent a development of systems theory, is somewhat different. With its focus of unpredictability and the emergence of new levels of order, it justifies skepticism about such managerialism and could be regarded as more in accordance with Bogdanov's ideas. But complexity theory has also been utilised by the proponents of capitalism. In this case it is more likely to be used by neo-liberals to justify the dismantling of the welfare state and the revival of laissez-faire capitalism than to manage society, although there is now a school within management science focussing on the

45. For an analysis of this see Robert Lilienfeld, The Rise of Systems Theory: An Ideological Analysis (New York: Wiley, 1978).

46. Mike Hales, 'Management Science and "The Second Industrial Revolution", , in Les Levidow, ed., Radical Science (London: Free Association Books, 1986), pp. 62-87, p. $72 \mathrm{f}$.

47. As Ilmari Susiluoto has shown in The Origins and Development of Systems Thinking in the Soviet Union (Helsinki: Suomalainen Tiedeakatemia, 1982). 
problem of how to manage complexity. ${ }^{48}$ From the perspective of the complexity theorists at the Santa Fe Institute, new order emerges through the free action of atomic individuals. It is this version of complexity theory that Steven Best and Douglas Kellner have criticised in this volume.

However, radical ideas should not be rejected because they have been appropriated and utilised by those with power within existing oppressive societies. It is almost inevitable that the most powerful ideas of radicals will be exploited by the existing ruling class, albeit in distorted form. If those calling for a radical transformation of society reject any ideas which have been appropriated and utilised in any way whatsoever within the existing social order, they will be left with very little to effect a social transformation. What is more important is to understand how radical ideas have been deformed and what aspects of them need to be upheld if their revolutionary potential is to be realised.

\section{The radical core of tektology}

There are a number of core features of tektology that underpin its radical potential; however, to put these in perspective, I will begin with an aspect of tektology which might not seem to be of great ideological significance. This is that tektology is emphatically committed to a process view of the world. What is radical about seeing the world as consisting of processes rather than things or substances? Perhaps the best way to answer this is to consider the obverse question, 'What is so oppressive about conceiving the world to consist of things or substances rather than processes?'. Marx provided an initial insight into this. A capitalist economy is characterised by the reification of labour processes and the products of labour as the condition for their exploitation. But this is only a specific instance of what is involved in treating any component of the world as something to be exploited. To see an animal or a tree as a thing is to see it only in relation to how it can be exploited. Obversely, to see an animal or tree as living is to see it as a process and thereby to appreciate its immanent dynamics and intrinsic value. Tektology is radical because it consistently views the world as a world of processes, whereas systems theory and complexity theory insofar as they have been utilised in the interests of prevailing powers are inconsistent in this regard and are prone to assuming that what really exists, whether these be systems or their components, are things.

What other implications follow from seeing the world as processes? To begin with, the dualisms that have emerged with hierarchical societies between what acts and what is acted upon, between consciousness and matter, spirit and nature, or reason and emotion, can be overcome. All can be intelligibly conceived as aspects of processes and their relations. Activity in such a world therefore has to be seen as participation with other dynamic processes, and 'products' as enduring potentialities to be used must be seen as generated from the world through the interaction between diverse processes. That is, it must be acknowl-

48. One of the better works in this regard is Stephen J. Guastello, Chaos, Catastrophe, and Human Affairs; Applications of Nonlinear Dynamics to Work, Organization, and Social Evolution (Mahway: New Jersey, 1995). 
edged and appreciated that individuals and their activities and 'products' are dependent on the perdurance and creative activity of other processes.

Since it is necessary to appreciate that the developments of society, culture and knowledge are themselves processes within the world, such a conception of the world requires reflexivity. The development of culture and knowledge must be appreciated as part of the self-creation of humanity, involving the creation of relations between people, between society and nature, and between individuals and society. As we saw, Bogdanov characterised the development of ideas, including tektology, through tektology. Just as at the end of the middle ages, ' $\mathrm{t}$ ] he new living content, bursting out of the framework of the old dogma, created new degressive forms for itself', tektolgy can be understood as the effort to create new degressive forms, facilitating new advances in the sciences. This advance in culture will facilitate not only new kinds of technology, but also new social forms. That is, as a contribution to culture they will become the components of new social relations. At the same time it must be recognised that all components of culture can only be accepted provisionally, that all science, all ideas, are open to question and to replacement by other ideas. If such ideas are to be components of a new democratic economic, political and social order, such a framework of concepts should be as simple as possible so that they can be easily mastered by all people and all people must be able to contribute to the development of such a culture, and be able to question (and reformulate) the basic framework of concepts which dominate it.

\section{Evaluating systems theory and complexity theory through tektology}

In the light of Bogdanov's tektology, how then should we evaluate systems theory and complexity theory? My contention is that when the aims and achievements of tektology have been appreciated, those aspects of systems theory and complexity theory which accord with it, or which are consistent with its basic aims, can be lauded, while tendencies which undermine these basic aims can be criticised. Von Bertalanffy, while being far more conservative than Bogdanov, had similar aims to overcome the dualism and fragmentation of prevailing thought and to provide people with the means to put a vast diversity of ideas in perspective. Many systems theorists have followed him, including Ervin Laszlo and the critical systems theorists. Their greatest defect is to have left out many of Bogdanov's insights, giving little place to the study of crises and radical transformations, or to the dynamics of culture and what is involved in reflexivity. To some extent complexity theory addresses these problems and as such can be regarded as an important contribution to developing the new cosmology Bogdanov called for. The work of Ilya Prigogine in chemistry, Stanley Salthe and Brian Goodwin and his colleagues in biology and Paul Ormerod in economics are significant advances in this regard. ${ }^{49}$ Other systems

49. See for example Ilya Prigogine, From Being to Becoming (San Francisco: Freeman, 1980); Stanley N. Salthe, Evolving Hierarchical Systems (New York: Columbia University Press, 1985); Brian Goodwin, How the Leopard Changed its Spots (London: Weidenfeld \& Nicolson, 1994) and Paul Ormerod, The Death of Economics (London: Faber and Faber, 1994). 
theorists and complexity theorists have had a different agenda-to develop these ideas into instruments of control, or to justify conservative social policies or the embracing of the free market. Effectively, they have appropriated fragments of systems theory and complexity theory into an expanded mechanistic cosmology in the service of the dominant culture. The challenge posed by the resurrection of Bogdanov's vision is to develop a consistently anti-reductionist version of these ideas. 